\title{
ETIOLOGIC RELATIONSHIP OF THE RI-67 AGENT TO “ACUTE RESPIRATORY DISEASE (ARD)"1
}

\author{
BY HAROLD S. GINSBERG, GEORGE F. BADGER, JOHN H. DINGLE, WILLIAM S. \\ JORDAN, JR, AND SIDNEY KATZ
(From the Departments of Preventive Medicine and Medicine, School of Medicine, Western Reserve University, and the University Hospitals, Cleveland, Ohio)

(Submitted for publication January 10, 1955 ; accepted February 9, 1955)

As the result of intensive studies of acute respiratory infection in military populations from 1941 to 1946, an entity termed "acute respiratory disease" was described by the Commission on Acute Respiratory Diseases (1-4). This syndrome, for convenience, was termed "ARD," and this designation will be employed hereafter. ARD is an acute febrile respiratory infection of short duration with both constitutional symptoms and localized respiratory symptoms characterized predominately by cough and hoarseness $(1,2)$. In addition, irritated throat, nasal obstruction, and chest pain were frequent complaints. Epidemiological investigation (1) as well as human transmission experiments $(3,4)$ indicated that the incubation period of this infection was five to six days, and that during convalescence there developed an homologous immunity but not heterologous resistance to common cold or primary atypical pneumonia (4). It was postulated as a result of these investigations $(1-4)$ that ARD was an entity distinguishable from other acute respiratory illnesses such as common cold, streptococcal pharyngitis and tonsillitis, and primary atypical pneumonia, and that it was caused by a single filterable agent, probably a virus, or a closely related group of agents. Attempts to isolate an agent in experimental animals and chick embryos were not successful.

Although ARD has not been recognized in epidemic form in civilian populations, similar infections such as non-streptococcal pharyngitis and grippe-like illnesses not caused by influenza vi-

1 This investigation was conducted under the sponsorship of the Commission on Acute Respiratory Diseases, Armed Forces Epidemiological Board, and was supported in part by the Office of The Surgeon General, Department of the Army, and by grants from the Brush Foundation, the Robert Hamilton Bishop, Jr. Endowment Fund, Mr. Philip R. Mather, and the Republic Steel Corporation. ruses are frequently observed. Moreover, ARD continues to be an important respiratory infection in the Armed Forces. These considerations have stimulated continued investigation of this disease in order to delineate it further and to isolate the causative agent or agents.

The multiple isolations of cytopathogenic agents from tonsils and adenoids grown in tissue culture by Rowe, Huebner, Gilmore, Parrott, and Ward (5) indicated the existence of a new group of viruses which propagate in the upper respiratory tract of man and suggested a new approach to the investigation of acute undifferentiated respiratory infections. Independently, Hilleman and Werner (6) isolated in tissue culture 5 strains of cytopathogenic agents from cases of acute respiratory diseases which occurred during an influenzalike epidemic at Fort Leonard Wood, Missouri, during the winter of 1952-53. The majority of illnesses which occurred during this epidemic resembled ARD; some had pulmonary infiltration and were considered to be primary atypical pneumonia. Neither cold hemagglutinins nor agglutinins to streptococcus MG developed in patients with the latter type of illness. Hilleman and Werner demonstrated that the majority of patients studied had a rise in neutralizing antibodies against one of the strains isolated, the RI-67 strain (6).

The isolation of an agent, presumably a virus, from cases of ARD (6) immediately suggested an opportunity to establish the etiology of ARD and to test directly the hypotheses proposed by the Commission on Acute Respiratory Diseases (1-4). In addition, it was of interest to determine the relationship of the agents isolated by Rowe and co-workers (5), called "adenoid degeneration" or "A.D." agents, to the RI-67 agent. The results of experiments carried out to study these points are the subject of this report. A 
preliminary summary of certain of these data has been presented elsewhere ( 7 ).

\section{MATERIALS AND METHODS}

Viruses. 2 The viruses employed were the RI-67 strain of the "new acute respiratory disease virus" isolated by Hilleman and Werner and the prototype strains of Types I, II, and III "adenoid degeneration" agents isolated by Rowe, Huebner, Gilmore, Parrott, and Ward (5).

Pools of seed virus were prepared by passage in strain HeLa cell cultures (8) grown in 32 ounce Duraglas prescription bottles. For the RI- 67 agent, $4 \mathrm{ml}$. of a $1: 2$ dilution prepared in Hanks balanced salt solution was inoculated onto a culture of $\mathrm{HeLa}$ cells. After 5 to 10 minutes at room temperature, $36 \mathrm{ml}$. of maintenance solution with 10 per cent chicken serum (8) was added. The adenoid degeneration agents, hereafter referred to as A.D. agents, were diluted $1: 3.16\left(10^{-0.5}\right)$ and $4 \mathrm{ml}$. inoculated onto each HeLa culture; the addition of $36 \mathrm{ml}$. of maintenance solution was subsequently made. Infected cultures were incubated at $36^{\circ} \mathrm{C}$. for three to seven days until complete cellular degeneration had occurred. Clumped cells still adherent to the glass were removed with a rubber policeman on a curved glass rod, and these cells disintegrated in the infected supernatant fluid by grinding with a Teflon homogenizer (9) for two minutes. The homogenization chamber was kept chilled by an ice-water bath, and cell disruption was accomplished with the aid of a small quantity of alundum. The homogenized suspension was centrifuged at $2,500 \mathrm{rpm}$. for 10 minutes in a refrigerated International centrifuge, and the supernatant stored in sealed glass ampules at $-70^{\circ} \mathrm{C}$.

Sera. Lyophilized and liquid sera from donors and recipients of filtrates were available from the human transmission experiments carried out by the Commission on Acute Respiratory Diseases at Gatlinburg, Tennessee, in 1943 (10), and Pinehurst, North Carolina, in 1944 and $1945(3,4,11)$. Lyophilized material had been stored at room temperature and liquid sera at $4^{\circ} \mathrm{C}$. Sera obtained from hospitalized patients with clinical respiratory illnesses were also used for neutralization titrations. These sera had been stored in the lyophilized, frozen $\left(-20^{\circ} \mathrm{C}\right.$. $)$ or liquid $\left(4^{\circ} \mathrm{C}\right.$.) state for varying periods since 1942. Many sera contained precipitated materials which were removed by centrifugation in the Spinco Model L centrifuge at $14,830 \mathrm{~g}$ for 15 minutes. All sera were heated at $56^{\circ} \mathrm{C}$. for 30 minutes before use.

Red Cross pools of gamma globulin for antibody titrations were supplied by Dr. Glen Smith of the Cleveland Department of Health and by Dr. W. McD. Hammon of the University of Pittsburgh Graduate School of Public Health.

2 The viruses were made available through the kindness of Dr. M. R. Hilleman, Army Medical Service Graduate School, and Dr. R. J. Huebner, Laboratory of Infectious Diseases, National Institutes of Health.
Tissue culture. The methods employed were modifications of those described by Scherer, Syverton, and Gey (8) for the propagation of the single cell line derived from an epidermoid carcinoma of the cervix of the uterus, designated strain HeLa. A HeLa cell culture was obtained from Dr. J. T. Syverton and has been maintained in serial passage for one year.

Cellular cultivation. Propagation of cells was carried out in bottles $(200 \mathrm{ml}$. square screw-cap Kimble neutraglass, or $32 \mathrm{oz}$. flat-side Duraglas prescription, sealed with white rubber stoppers), or in 16 by $150 \mathrm{~mm}$. screwcap test tubes. Cells in bottles and tubes were incubated at $36^{\circ} \mathrm{C}$. in a stationary position. Tubes were maintained at a $5^{\circ}$ angle in specially constructed racks, and bottles were kept flat on the incubator shelves. For cultivation of cells a nutritive medium was employed composed of 25 per cent human serum, 2 per cent chick embryo extract (50 per cent), 5 per cent chick embryo ultrafiltrate ( 50 per cent), ${ }^{3}$ and 68 per cent Hanks balanced salt solution. Penicillin and streptomycin were added to make a final concentration of 50 units and 0.5 mg. per milliliter of each, respectively. For preparation and distribution of cell suspensions, silicon coated glassware was used. With a rubber policeman placed on the curved end of a glass rod, HeLa cells were scraped from the bottle wall into 2 to $6 \mathrm{ml}$. of the clarified nutritive fluid in which they had been grown. Trypsin was not employed. The cellular sheets and clumps were disrupted by drawing back and forth through a 22 gauge needle attached to a $3 \mathrm{ml}$. Cornwall spring-activated syringe for 1.5 to 3 minutes. By this method a suspension was prepared composed almost entirely of single cells with only an occasional small clump of cells present. The number of cells per milliliter of suspension was determined by direct microscopic enumeration in a hemocytometer. The concentration of cells was adjusted to 80,000 per ml. by dilution with nutrient fluid and dispensed into bottles in $10 \mathrm{ml}$. (Kimble bottle) or $30 \mathrm{ml}$. (Duraglas bottle) volume with a pipette, or into test tubes in $0.7 \mathrm{ml}$. volume with a spring-activated Cornwall syringe. To obtain a complete sheet of cells in bottles required two to four days' incubation. Each day $5 \mathrm{ml}$. (Kimble bottle) or $15 \mathrm{ml}$. (Duraglas bottle) of nutrient fluid was removed and a like volume of fresh nutritive fluid was added. If essential, $\mathrm{pH}$ was adjusted to 7.6 to 7.8 with 1.4 per cent $\mathrm{NaHCO}_{3}$. In tubes, HeLa cells formed into sheets and were ready to be infected within 24 hours in all but rare instances.

Infection of $\mathrm{HeLa}$ cell cultures. All nutritive fluid was removed as completely as possible and cultures were washed 2 times with Hanks balanced salt solution containing antibiotics. For bottle cultures each wash was done with $20 \mathrm{ml}$. or $50 \mathrm{ml}$. of fluid, and for tubes, $2 \mathrm{ml}$. per wash was employed. The liquid phase employed for infection was a synthetic fluid, maintenance solution (MS), containing 10 per cent chicken serum (8) and antibiotics. For test tube cultures, $0.8 \mathrm{ml}$. of MS plus

\footnotetext{
${ }^{3}$ Obtained from Microbiological Associates, Inc., Bethesda, Maryland.
} 
chicken serum was employed; for bottles (Duraglas), 36 ml. was used.

Nextralization titration. Serial four-fold dilutions of each serum were prepared in Hanks balanced salt solution. To $0.3 \mathrm{ml}$. of each dilution was added an equal volume of virus diluted to contain 10 to 50 cytopathogenic tissue culture doses (TCD) per $0.1 \mathrm{ml}$. Serum-virus mixtures were incubated at room temperature (22 to $24^{\circ}$ C.) for 30 minutes, after which period each of two tissue culture tubes was inoculated with $0.2 \mathrm{ml}$. of each serum dilution-virus mixture. The majority of these titrations was carried out with $\mathrm{HeLa}$ cell cultures in tubes purchased from Microbiological Associates, Inc. These tubes were prepared by methods similar to those described above. The results of neutralization and infectivity titrations in tubes prepared in either laboratory were similar, although a longer (two to four days) period of incubation was required to show maximum cytopathogenic changes in cultures made in this laboratory. Tubes were observed microscopically at least every two days and the final reading was made on the sixth day after inoculation. A culture was considered to be infected when round cells had developed throughout the culture and numerous cluster-like clumps of these cells had formed. In practically all titrations the end-point was sharp and the appearances of both tubes inoculated with a single serum dilution-virus mixture were similar. The end-point is expressed as the final dilution of serum in the serum-virus mixture which protected the cultured $\mathrm{HeLa}$ cells from viral cytopathogenic effects in both culture tubes. In the few instances in which protection was observed in only one of the two tubes, the extrapolation necessary to determine the exact end point was calculated. The proper serum and uninoculated tube controls were included in each experiment. All sera from a single individual were titrated on the same day.

Infectivity titration. Serial $0.5 \log _{10}(1: 3.16)$ dilutions were prepared in Hanks balanced salt solution, and to each culture tube was added $0.1 \mathrm{ml}$. of virus dilution. Two tubes per dilution were employed. The final observation of cultures was made on the sixth day after viral inoculation and the end-point is expressed as the initial dilution of virus which initiated specific cytopathogenic alterations of the HeLa cells in at least one of the two cultures. In the great majority of titrations changes were similar in both tissue culture tubes inoculated with a single dilution. When necessary, the proper calculations to determine the 50 per cent end-point (12) were made.

RESULTS

\section{Neutralization titrations with sera from donors of respiratory secretions}

Patients with illnesses considered to be clinically characteristic of primary atypical pneumonia (PAP), acute respiratory disease of recruits (ARD), bronchitis resembling atypical pneu-
TABLE I

Results of neutralization titrations with sera from dowors of respiratory secretions for human transmission experiments

\begin{tabular}{|c|c|c|c|c|}
\hline \multicolumn{2}{|c|}{$\begin{array}{l}\text { Volunteer } \\
\text { experiment }\end{array}$} & \multirow{2}{*}{$\begin{array}{c}\begin{array}{c}\text { Clinical syndrome } \\
\text { of donor }\end{array} \\
\text { Primary atypical } \\
\text { pneumonia (PAP) }\end{array}$} & \multirow{2}{*}{$\begin{array}{c}\begin{array}{c}\text { Number } \\
\text { of } \\
\text { donors }\end{array} \\
6\end{array}$} & \multirow{2}{*}{$\begin{array}{c}\begin{array}{c}\text { Number } \\
\text { of rises } \\
\text { in anti- } \\
\text { body } \\
\text { titer }\end{array} \\
0\end{array}$} \\
\hline Gatlinburg & 1943 & & & \\
\hline Pinehurst & 1944 & $\begin{array}{l}\text { pneumonia (PAP) } \\
\text { Primary atypical }\end{array}$ & 6 & 0 \\
\hline Pinehurst & 1945 & $\begin{array}{l}\text { Primary atypical } \\
\text { pneumonia (PAP) }\end{array}$ & 1 & 0 \\
\hline Pinehurst & 1945 & $\begin{array}{l}\text { Acute respiratory } \\
\text { disease (ARD) }\end{array}$ & 1 & 1 \\
\hline Pinehurst & 1945 & $\begin{array}{l}\text { Bronchitis resembling } \\
\text { atypical pneumonia } \\
\text { (Br-AP) }\end{array}$ & 1 & 1 \\
\hline Pinehurst & 1945 & $\begin{array}{c}\text { Common cold, mild } \\
\text { (CC) }\end{array}$ & 1 & 0 \\
\hline Pinehurst & 1945 & $\begin{array}{l}\text { Common cold, severe } \\
\text { (S-CC) }\end{array}$ & 1 & 0 \\
\hline
\end{tabular}

monia (Br-AP), and cases of common cold, severe ( $\mathrm{S}-\mathrm{CC})$ and mild $(\mathrm{CC})$, were selected by the Commission on Acute Respiratory Diseases to provide infected respiratory secretions for human transmission experiments $(3,4)$. Sera from these patients had been saved and were available for this study. To determine whether the RI-67 agent isolated by Hilleman and Werner (6) was associated with any of these acute respiratory infections, neutralization titrations were carried out with this virus and the reconstituted lyophilized sera obtained during the acute and convalescent stages of the donors' illnesses. The results of these titrations are summarized in Table I. Development of antibodies against the RI-67 agent occurred in the patients who had ARD and bronchitis resembling atypical pneumonia, but not in those with primary atypical pneumonia or with the severe or mild forms of common cold. The

TABLE II

Neutralization titers of sera from: donors in Pinehurst 1945 human transmission experiment

\begin{tabular}{lccc}
\hline \hline \multirow{2}{*}{$\begin{array}{c}\text { Clinical } \\
\text { oyndrome } \\
\text { of donor* }\end{array}$} & $\begin{array}{c}\text { Neutralization titer } \\
\text { serum }\end{array}$ & $\begin{array}{c}\text { Convalescent } \\
\text { serum }\end{array}$ & $\begin{array}{c}\text { Antibody } \\
\text { rise }\end{array}$ \\
\hline PAP & $1: 8$ & $1: 8$ & 0 \\
ARD & $<1: 8$ & $1: 32$ & + \\
Br-AP & $<1: 8$ & $1: 512$ or $>$ & + \\
CC & $<1: 8$ & $<1: 8$ & 0 \\
S-CC & $1: 8$ & $1: 8$ & 0 \\
\hline
\end{tabular}

* See Table I for designations. 
exact titers of antibodies in sera from donors whose secretions were employed in the Pinehurst, 1945 experiment are presented in Table II. The significance of the high titer of antibodies which developed in the patient with bronchitis (Br-AP) as compared to the ARD donor is not clear. These data do suggest, however, that the etiologic agent or agents responsible for these two diseases were related to the RI- 67 agent isolated by Hilleman and Werner (6).

Neutralization titrations with sera from recipients of $A R D$, primary atypical pneumonia, and severe common cold secretions

Transmission experiments carried out by the Commission on Acute Respiratory Diseases in 1945 indicated that the respiratory diseases desig- nated as ARD, primary atypical pneumonia, and common cold were transmissible by bacteria-free filtrates of respiratory secretions and were indeed different entities $(3,4)$. Neutralization titrations carried out with sera from donors of these secretions against the RI-67 agent not only tended to confirm these findings, but also suggested that this new agent was etiologically associated with ARD. To extend these preliminary findings, titrations were carried out with sera from recipients in the 1945 transmission experiments. The results of these titrations are presented in Figure 1 along with the clinical results of the inoculation of control autogenous' filtrates and infected materials from patients with ARD; primary atypical pneumonia and common cold $(1,4)$. A rise in neutralizing antibodies occurred only in individuals

\section{FILTRATE ARD}

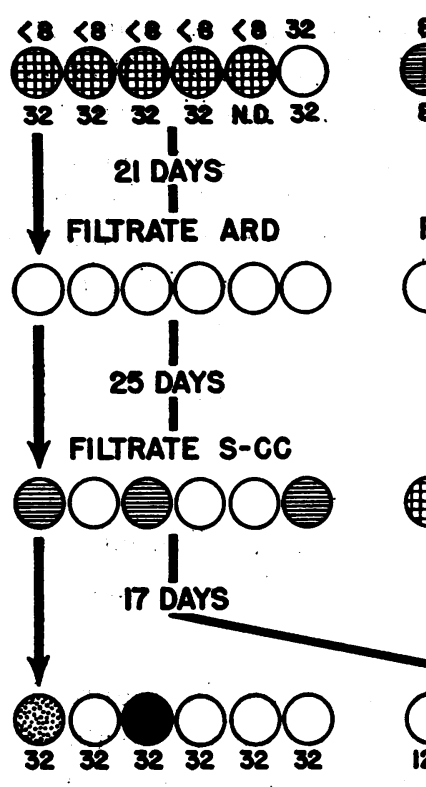

FILTRATE S-CC

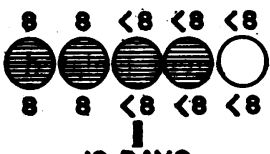

19 DAYS

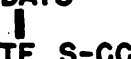

TRATE S-CC
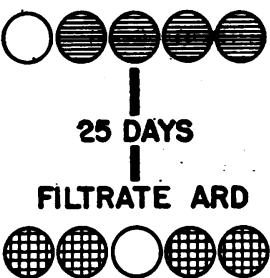

16 DAYS

\section{CONTROLS-AUTOGENOUS FILTRATES}

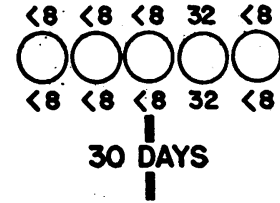

CONTROLS-FILTRATE S-CC

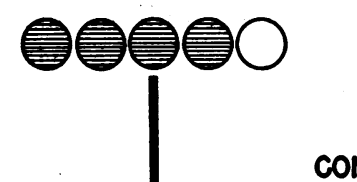

CONTROLS-FILTRATE ARD

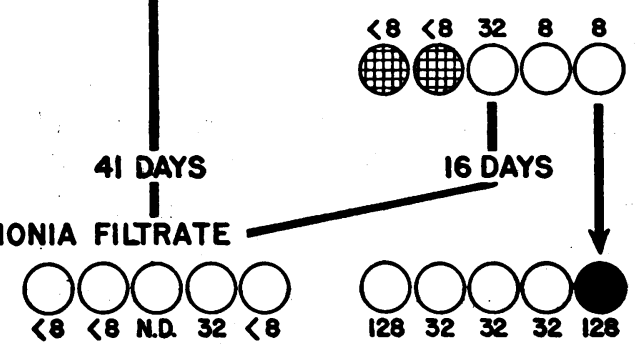

曲 ARD
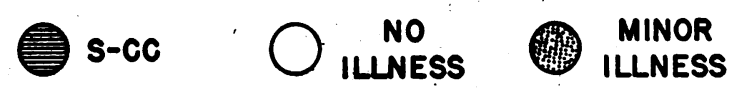

PRIMARY ATYPICAL PNEUMONIA

Fig. 1. Results of Neutralization Trtrattons Carrigd OUt with the RI-67 Agent and Sera Obtained from Human Volunteres before and aftzr Inoculation with Filtrred Secretions from Patients with ARD, Severe Common Cold (S-CC), or Primary Atypical Pneumonia

Some recipients were also given filtered homologous secretions. Neutralization titers are indicated in relation to the appropriate inoculation. Each circle represents a volunteer and the shadings indicate the occurrence of illness. The sequence of events for each volunteer is represented by a single vertical column of circles. 
who received ARD secretions and not in volunteers inoculated with autogenous, common cold or primary atypical pneumonia filtrates. In those instances in which sera were available two to three weeks following inoculation of ARD secretions, it was possible to demonstrate that antibodies developed in relation to the inoculation and, in most instances, concurrent with a clinical infection. Only two recipients failed to develop either detectable increase in antibodies or an illness; both had circulating antibodies at the time of intranasal inoculation of ARD secretions. There were three instances in which there was an increase in neutralizing antibodies directed against the RI-67 agent in the absence of a recognizable clinical illness; two of the individuals had antibodies when ARD secretions were inoculated. Those recipients initially inoculated with ARD filtrate who developed antibodies against the RI-67 agent, did not have second attacks of clinical illness when challenged with the ARD filtrate 21 days after the first inoculation. Furthermore, a subsequent rise in antibody titer did not occur. When volunteers were inoculated intranasally with severe common cold (S-CC) filtrate 25 days afterwards, clinical infections occurred in three out of six individuals. They were also susceptible to infection by the primary atypical pneumonia (PAP) filtrate. Conversely, volunteers given S-CC filtrate were not only susceptible to consecutive common cold infections, but subsequently became ill when inoculated with ARD filtrate 25 days after the second S-CC filtrate inoculation. Moreover, these volunteers were also susceptible to infection by the PAP filtrate. The only sera available in this instance to permit demonstration of a rise in antibody to the RI-67 agent were those obtained after the PAP challenge. The group of five volunteers, inoculated successively with autogenous, common cold, and primary atypical pneumonia filtrates, failed to show rises in neutralizing antibody to the RI-67 virus. This result indicates that the rise in specific antibodies in the other groups was not due to the inoculation of primary atypical pneumonia filtrate. Thus the data presented in Figure 1 show that the increase in immune bodies to RI-67 virus resulted from the ARD infection.

The results of neutralization titrations carried out on sera from all recipients inoculated with
TABLE III

Results of neutralisation titrations with sera from recipients in Pinehurst 1945 human volunteer transmission experiment

\begin{tabular}{lcc}
\hline \hline Disease of donor & $\begin{array}{c}\text { Number of } \\
\text { recipients }\end{array}$ & $\begin{array}{c}\text { Number of } \\
\text { rises in } \\
\text { antibody } \\
\text { titer }\end{array}$ \\
\hline ARD & 24 & 20 \\
Atypical pneumonia & 15 & 0 \\
Common cold, severe & 25 & 0 \\
\hline
\end{tabular}

respiratory secretions from donors with $A R D$, severe common cold, or primary atypical pneumonia are summarized in Table III. These results add further evidence that individuals infected with secretions from a patient with ARD developed antibodies against the RI-67 agent, but those inoculated with secretions from patients with other acute respiratory diseases had no increase in antibody titer against this agent.

The data presented strongly indicate that the new agent isolated by Hilleman and Werner (6) is either immunologically closely related to or identical with the agent present in secretions obtained from a donor ill with ARD but was not present in respiratory secretions from donors with common cold or primary atypical pneumonia. Moreover, these studies suggest that this new agent, presumably a virus, is etiologically related to ARD but not to the other entities under investigation.

\section{Correlation of results of neutralization titrations and occurrence of illness in recipients of $A R D$ filtrates}

From the results presented in Figure 1 and Table III it was possible to correlate the occurrence of illness in recipients of the ARD filtrate with the results of neutralization titrations carried out with sera from these recipients and the RI-67 agent. This correlation, summarized in Table IV, demonstrates a striking relationship between the absence of neutralizing antibodies in the pre-inoculation sera and the subsequent occurrence of illness; and conversely, between the presence of antibodies in sera obtained from recipients before intranasal inoculation and failure to manifest illness after inoculation of infected filtrate. Of the 24 volunteers inoculated, 18 or 75 per cent became 
TABLE IV

Correlation of results of neutralization titrations with RI-67 agents and occurrence of illness in recipients of $A R D$ secretions

\begin{tabular}{|c|c|c|c|c|c|c|}
\hline \multirow[b]{2}{*}{$\begin{array}{l}\text { Antibody } \\
\text { response }\end{array}$} & \multicolumn{3}{|c|}{ III } & \multicolumn{3}{|c|}{ Not ill } \\
\hline & $\begin{array}{l}\text { Antibody } \\
\text { in pre- } \\
\text { inoculation } \\
\text { serum }\end{array}$ & $\begin{array}{c}\text { No antibody } \\
\text { in pre- } \\
\text { inoculation } \\
\text { gerum }\end{array}$ & Total & $\begin{array}{l}\text { Antibody } \\
\text { in pre- } \\
\text { inoculation } \\
\text { eerum }\end{array}$ & $\begin{array}{c}\text { No antibody } \\
\text { in pre- } \\
\text { inoculation } \\
\text { serum }\end{array}$ & Total \\
\hline $\begin{array}{l}\text { Rise } \\
\text { No rise } \\
\text { Total }\end{array}$ & $\begin{array}{l}2 \\
1 \\
3\end{array}$ & $\begin{array}{r}15 \\
0 \\
15\end{array}$ & $\begin{array}{r}17 \\
1 \\
18\end{array}$ & $\begin{array}{l}2 \\
3 \\
5\end{array}$ & $\begin{array}{l}1 \\
0 \\
1\end{array}$ & $\begin{array}{l}3 \\
3 \\
6\end{array}$ \\
\hline
\end{tabular}

ill; 15 or 83 per cent of these had no antibodies, and all developed neutralizing antibodies following inoculation. Only three (17 per cent) of those who became ill had antibodies in their pre-inoculation sera and two of the three had an increase in antibody titer in their post-inoculation sera. In sharp contrast were the six, or 25 per cent, of the volunteers who showed no evidence of clinical illness following intranasal inoculation of the ARD filtrate. Five of the six, or 83 per cent, had circulating immune bodies when inoculated. There was only one volunteer without antibodies at time of intranasal inoculation who did not become ill; antibodies did develop following exposure to the ARD filtrate. To summarize somewhat differently, of 24 inoculated with the ARD filtrate, 16, or 67 per cent, had no circulating antibodies when challenged; all developed antibodies against the RI-67 agent and 15, or 94 per cent, became ill. Eight, or 33 per cent, of the volunteers had antibodies at the onset of the experiment; five or 62 per cent, of this group resisted infection with the ARD agent. For comparison, it is of interest that no neutralizing antibodies were present in the pre-inoculation sera of 76 per cent of the 62 volunteers used in the Pinehurst, 1945 experiment, a percentage comparable to the 67 per cent of the 24 recipients of the ARD filtrate who had no immune bodies in their pre-inoculation sera.

These data indicate that as a result of inoculation of an ARD filtrate into human volunteers, illness developed in a large proportion (94 per cent) of those who did not have circulating neutralizing antibodies against the RI-67 agent. Furthermore, it may be concluded from these data that the presence in blood of antibodies against this virus is related to an undetermined degree to protection against the causative agent of ARD.
Neutralization titrations with sera from recipients of bronchitis resembling atypical pneumonia and mild common cold filtrates

Neutralization titrations carried out with the acute and convalescent phase sera from a patient with a disease syndrome termed "bronchitis resembling atypical pneumonia (Br-AP)" (3) exhibited a marked increase in antibodies against the RI-67 agent (Table I). Filtered respiratory secretions from this patient were inoculated into human volunteers and pre- and post-inoculation sera from the recipients were subsequently tested. Sera from individuals in the same experiment who were inoculated with secretions from a patient in the acute stage of a mild common cold (CC) were also titrated. The results of these neutralization titrations, as well as the occurrence of illnesses in the inoculated volunteers, are summarized in Figure 2. Only 4 of the 10 volunteers inoculated with $\mathrm{Br}$-AP secretions developed a clinical illness. Sera were available from only three of these individuals, all of whom developed a small increase in neutralizing antibodies. The increase in titer demonstrable, although small, was considered to be significant as the titers were reproducible on repeated neutralization tests. Of the six recipients who showed no indication of infection following intranasal inoculation, four developed an increase in neutralizing antibodies; the rise in two instances was of greater magnitude than noted in sera from recipients with clinical illnesses. None of the recipients who received the common cold filtrate had an increase in neutralizing antibodies against the RI-67 agent. In addition, it will be noted that the recipients given the bronchitis filtrate were not subsequently resistant to the common cold, nor did homologous immunity develop in those who were given common cold filtrate 


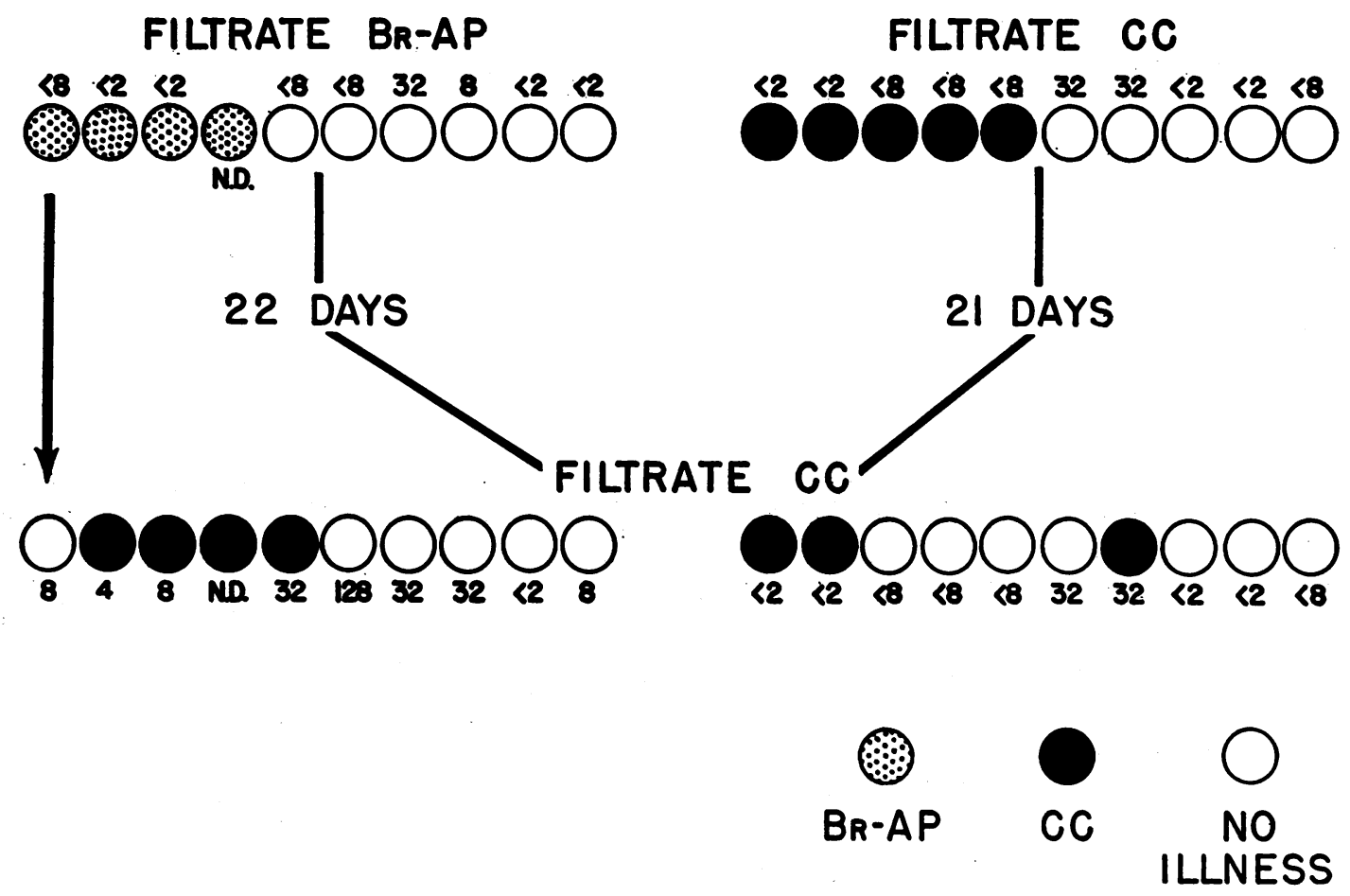

Fig. 2. Results of Neutrauzation Timrations Carried Out with the RI-67 Agent and Sera Obtained from Human Volunterers before and a atrer Inoculation with Filtered Secretions from Illnesses Termed Common Cold (CC) or "Bronchitts Resembling Atypical Preumonia" (Br-AP)

The sequence of events in a single volunteer is represented by a single vertical column of circles. Each circle represents a volunteer and the shading indicates the occurrence of illness. Neutralization titers are indicated in relation to the appropriate inoculation.

initially and challenged with the same filtrate 21 days later.

A correlation of the results of the neutralization titrations and clinical illnesses in the recipients of "bronchitis resembling primary atypical pneumonia" (Br-AP) filtrate is presented in Table V. Although illness occurred only in volunteers who had no detectable RI-67 antibodies, a similar number of volunteers without circulating specific im- mune bodies in their pre-inoculation sera had no clinical infection following inoculation of the Br-AP filtrate. Two individuals who had RI-67 antibodies before inoculation of the $\mathrm{Br}-\mathrm{AP}$ filtrate also remained well. From these data one can conclude that an agent immunologically related to the RI-67 agent was contained in the $\mathrm{Br}$-AP filtrate, but these data do not indicate whether or not this agent was responsible for the

TABLE V

Correlation of results of neutralization titrations with RI-67 agent and occurrence of illness in recipients of bronchitis resembling atypical pneumonia (Br-AP) secretions

\begin{tabular}{|c|c|c|c|c|c|c|}
\hline \multirow[b]{2}{*}{$\begin{array}{l}\text { Antibody } \\
\text { response }\end{array}$} & \multicolumn{3}{|c|}{ III } & \multicolumn{3}{|c|}{ Not ill } \\
\hline & $\begin{array}{l}\text { Antibody } \\
\text { in pre- } \\
\text { inoculation } \\
\text { serum }\end{array}$ & $\begin{array}{l}\text { No antibody } \\
\text { in pre- } \\
\text { inoculation } \\
\text { serum }\end{array}$ & Total & $\begin{array}{l}\text { Antibody } \\
\text { in pre- } \\
\text { inoculation } \\
\text { serum }\end{array}$ & $\begin{array}{l}\text { No antibody } \\
\text { in pre- } \\
\text { inoculation } \\
\text { serum }\end{array}$ & Total \\
\hline $\begin{array}{l}\text { Rise } \\
\text { No rise } \\
\text { Total }\end{array}$ & $\begin{array}{l}\mathbf{0} \\
\mathbf{0} \\
\mathbf{0}\end{array}$ & $\begin{array}{l}3 \\
0 \\
3\end{array}$ & $\begin{array}{l}3 \\
0 \\
3^{*}\end{array}$ & $\begin{array}{l}1 \\
1 \\
2\end{array}$ & $\begin{array}{l}3 \\
1 \\
4\end{array}$ & $\begin{array}{l}4 \\
2 \\
6\end{array}$ \\
\hline
\end{tabular}

* No sera were available from one volunteer who became ill (see Figure 2). 
clinical infections observed in the four recipients who became sick. The relatively few illnesses which were induced in these volunteers, as well as the extreme mildness of the infection (3), may have influenced these results considerably.

\section{Results of neutralization titrations with sera from $A R D$ epidemics at military installations}

Thus far, ARD has been recognized only as a disease which occurs in epidemics in military recruits. To obtain further evidence concerning the etiologic relationship of the epidemic respiratory disease, ARD, to the RI-67 agent isolated by Hilleman and Werner (6), sera from soldiers who experienced ARD in epidemics which occurred at three different military installations (Fort Bragg, North Carolina; Warren Air Force Base, Wyoming; and Sampson Air Force Base, New York) from 1942 to 1953 were titrated for neutralizing antibodies. The results of these titrations, summarized in Table VI, indicate that numerous cases of ARD at Fort Bragg and Sampson Air Force Base in 1942 and 1953, respectively, were associated with and probably caused by the RI-67 agent. It is clear, however, that all illnesses termed ARD were not related to this virus. At Fort Bragg, 1944 and 1945, and Warren Air Force Base, 1949 and 1951, although a rise in titer of neutralizing antibodies directed against this agent was noted in occasional cases, the majority of those examined had no increase in these specific immune bodies.

Several different interpretations may be attached to these data: 1) The clinical syndrome termed ARD may be caused by a number of unrelated viruses; 2 ) a single class of agents may induce ARD but more than one immunological type

TABLE VI

Results of neutralization titrations with sera from $A R D$ patients at military installations

\begin{tabular}{ccc}
\hline \hline Camp & Year & $\begin{array}{c}\text { Antibody } \\
\text { rise }\end{array}$ \\
\hline Ft. Bragg & 1942 & $10 / 12^{*}$ \\
& 1944 & $8 / 35$ \\
Warren AFB & 1945 & $1 / 12$ \\
Sampson AFB & 1949 & $1 / 3$ \\
& 1951 & $0 / 4$ \\
& 1953 & $13 / 21$ \\
\hline
\end{tabular}

* Numerator $=$ number antibody rise; denominator $=$ number tested. may exist; 3) during a sharp single wave epidemic a single immunologic type may be implicated, whereas at other times a number of types may compete in the production of sporadic cases; or 4) the RI-67 agent occasionally may propagate and stimulate the production of specific antibodies in patients with ARD, although it is not the specific causative agent of the clinical disease observed. The evidence available suggests that the last interpretation is unlikely, but does not permit exclusion of any of the other possibilities.

\section{Neutralization titrations with pooled gamma glob- ulin and RI-67 agent}

An estimation of the prevalence of the RI-67 agent in the civilian population could be readily obtained by the determination of the presence of antibodies directed against it in gamma globulin prepared from pooled Red Cross plasma. Seven pools were tested; all contained neutralizing antibodies in titers of $1: 32$ ( 1 pool) or $1: 128$ ( 6 pools). Although in low dilutions (1:8 or less) each sample employed had a deleterious effect upon HeLa cells, this did not interfere with the end-point determination which in every instance was at least four-fold higher than the toxic effect of the gamma globulin. One may deduce from these data that the RI-67 agent or one immunologically related to it does propagate in human hosts in the civilian population, and that either infections by this agent occur frequently, or antibodies which develop as a result of infection persist for a relatively long period of time.

\section{Neutralization titrations with A.D. agents (Rowe and co-workers) and sera from donors and recipients in 1945 human transmission experi- ment}

Evidence already presented suggests that the RI-67 agent isolated by Hilleman and Werner (6) is etiologically related to the disease entity ARD. From tissues obtained at routine tonsillectomies and adenoidectomies, Rowe and co-workers isolated a number of agents which, in HeLa cell tissue cultures, appeared to have certain characteristics similar to the RI-67 agent (5). It was therefore of interest to compare these agents in neutralization titrations to determine: 1) whether antibodies against the A.D. agents 
TABLE VII

Results of neutralization titrations with Type II A.D. agent and sera from donors of secretions for Pinehurst, 1945 experiment

\begin{tabular}{lrcc}
\hline \hline & \multicolumn{2}{c}{ Titer } & \\
\cline { 2 - 3 } Syndrome* & $\begin{array}{r}\text { Acute } \\
\text { serum }\end{array}$ & $\begin{array}{c}\text { Convalescent } \\
\text { serum }\end{array}$ & Rise \\
\hline PAP & $<1: 8$ & $<1: 8$ & 0 \\
ARD & $1: 8$ & $1: 8$ & 0 \\
Br-AP & $1: 8$ & $1: 32$ & + \\
CC & $<1: 8$ & $<1: 8$ & 0 \\
S-CC & $<1: 8$ & $<1: 8$ & 0
\end{tabular}

* See Table I for designations.

developed during the clinical infections under study; and 2) the immunological relationship between the RI-67 and A.D. agents. The results of titrations carried out with the Type II agent and sera from donors of respiratory secretions in the 1945 experiment are presented in Table VII. A small increase in circulating antibodies occurred in the donor with "bronchitis resembling primary atypical pneumonia" but not in donors who had $A R D$, primary atypical pneumonia, or common cold, mild or severe. Titrations were next carried out with sera from all recipients who received the Br-AP filtrate as well as with sera from a number of recipients who received the ARD filtrate and had an increase in antibody titer against the RI-67 agent. From the results of these titrations with the A.D. Type II agent, summarized in Table VIII, it is noted that a rise in antibody titer occurred in only 1 of 13 recipients who received ARD filtrate and 1 out of 9 volunteers inoculated with the Br-AP filtrate. In each instance the titer increase was from $1: 8$ in the acute phase serum to $1: 32$ in the convalescent serum. It should be emphasized that all pairs of sera tested from ARD filtrate recipients and 7 of the 9 pairs from volunteers given $\mathrm{Br}$ - $\mathrm{AP}$ had a rise in antibody to the RI-67 agent. When Types I and III A.D.

TABLE VIII

Results of neutralization titrations carried out with Type II $A . D$. agent and sera from recipients of $A R D$ and bronchitis $(B r-A P)$ filtrates

\begin{tabular}{cc}
\hline $\begin{array}{c}\text { Recipients } \\
\text { given } \\
\text { filtrate }\end{array}$ & $\begin{array}{c}\text { Rise in Type II } \\
\text { neutralizing } \\
\text { antibody titer }\end{array}$ \\
\hline ARD & $1 / 13^{*}$ \\
Br-AP & $1 / 9$ \\
\hline
\end{tabular}

* Numerator = number showing antibody rise ; denominator $=$ number tested. agents became available there were insufficient quantities of these sera to perform further titrations. Paired sera from eight other recipients of ARD filtrate, however, were tested to determine whether an increase in antibodies against the Type I and III agents occurred concomitantly. All of these recipients had a clinical illness and manifested a rise in the RI-67 neutralizing antibody titer. In not a single instance could a rise in antibody titer against either A.D. agent be demonstrated. In addition sera obtained from cases of ARD at Sampson Air Force Base in 1953 were titrated for antibodies against the 3 types of agents. Although 13 out of 21 showed an increase in titer for the RI-67 virus (Table VI), there were no rises for the A.D. agents. Neutralization titrations carried out with other sera, from human cases and immunized animals (13), clearly indicated that there was no immunological relationship demonstrable by this technique between the RI-67 agent isolated by Hilleman and Werner (6) and the 3 immunological types of A.D. agents obtained from tonsils and adenoids by Rowe, Huebner, Gilmore, Parrott, and Ward (5). Moreover, there was no increase in neutralizing antibodies to the A.D. agents in sera from two patients with respiratory infections observed during the winter of 1954 in which a rise in neutralizing antibodies directed against the RI-67 agent occurred. Conversely, in a single instance in which an increase in antibodies directed against Type III agent occurred, immune bodies specific for the RI-67 virus did not develop. By complement-fixation titrations, however, an antigenic relationship between the RI-67 and A.D. agents can be demonstrated $(6,13$-See Addendum).

\section{DISCUSSION}

The serological studies presented demonstrate that, in sera from a donor of filtered ARD respiratory secretions as well as recipients of this filtrate, there developed neutralizing antibodies directed against the RI-67 agent isolated by Hilleman and Werner (6); that illness occurred in the great majority of recipients who had no antibodies in their pre-inoculation sera; that a rise in antibody titer occurred in all recipients in whom the pre-inoculation sera were devoid of neutralizing antibodies; and that the majority of recipients 
whose pre-inoculation sera contained neutralizing immune bodies were resistant to infection and did not have a further increase in neutralizing antibodies. The donor with the infection termed "bronchitis resembling atypical pneumonia," which clinically could not be easily distinguished from ARD, also had a rise in titer of antibodies to the RI-67 agent. Moreover, seven of the nine recipients of filtered respiratory secretions from this donor developed antibodies against this agent, but one could not directly correlate the occurrence of illness and rise in antibody titer with the presence or absence of antibodies in the pre-inoculation sera. Insufficient data are available to permit clear interpretations of these serologic results. Neutralizing antibodies to the RI-67 agent did not develop in either donors or recipients of common cold or primary atypical pneumonia filtrates.

It might be expected that the presence of an agent in secretions inoculated into humans would stimulate antibody formation against this agent if propagation of the agent ensued. This series of events does not alone provide conclusive evidence that illnesses which occurred in recipients subsequent to inoculation of these secretions were causally effected by the agent in question. The excellent correlation of absence of antibodies in preinoculation sera with occurrence of illness, and antibody rise, and conversely, the presence of circulating immune bodies at time of inoculation with resistance to infection and lack of antibody development, constitute strong evidence that the agent in question actually initiated the infection. Such was the case with ARD and the RI-67 agent. The fact that this agent or one closely related to it immunologically was associated with epidemics of ARD and not with epidemics of other acute respiratory infections is further evidence that the RI-67 agent isolated by Hilleman and Werner from cases resembling ARD (6) is indeed the etiologic agent, or at least one of the agents, which causes this respiratory infection. The data available, although still meagre, do suggest that other agents, possibly biologically closely related but immunologically different, also initiate epidemic and sporadic cases of this disease.

The question inevitably arises relative to what criteria are necessary to prove the etiologic relationship of a new agent to a clinical disease. For this purpose, many deem it essential to reproduce the infection in humans by inoculation of the new agent. It is proposed however, that it should be possible to obtain sufficient data from detailed clinical and epidemiological studies correlated with laboratory investigation to establish the etiologic relationship of a newly isolated agent with most infectious diseases. The data of importance might be categorized as follows: 1) Isolation of the agent should be possible from the majority of patients with the disease in question; the agent should be obtained from infected tissue or from secretions related to this tissue; 2) Specific antibodies directed against the new agent should develop in relation to infection; and 3) Resistance to infection should be correlated with presence of type specific, neutralizing antibodies; conversely, susceptibility should be related to absence or low titer of these specific antibodies. Perhaps the most definitive evidence in relation to these three points can be obtained when the disease in question occurs in a sequential or epidemic fashion in defined population groups. Data on each of these points have been obtained with the RI-67 agent and ARD and presented by Hilleman and Werner (6) and the present investigation.

Although the epidemic of acute respiratory disease studied by Hilleman and Werner (6) was that of an influenza-like illness considered to be ARD, the RI-67 strain of cytopathogenic agents was isolated from a patient who had a pulmonary infiltration. This infection was diagnosed to be primary atypical pneumonia although a rise in cold hemagglutinins or agglutinins to streptococcus MG did not occur (14). The data presented (Table I, Figure 1) indicate that in hospitalized patients and human volunteers a number of classical cases of primary atypical pneumonia of the type associated with a rise of cold hemagglutinins was not caused by the RI-67 agent. In addition, a number of hospitalized cases considered clinically to be primary atypical pneumonia in whom no cold hemagglutinins or streptococcus MG agglutinins developed were investigated; none had a rise in titer of neutralizing antibodies against the RI-67 agent. Of 22 cases of ARD which occurred at Sampson Air Force Base in 1953, pulmonary infiltration by $\mathrm{x}$-ray was noted in four cases. Three of these patients manifested an increase in RI-67 neutralizing antibodies. Further laboratory and detailed clinical studies concerning these ill- 
nesses were not available. These data suggest that pulmonary infiltration may develop during $A R D$. In the absence of information relative to the etiology of these infections, these cases would be termed primary atypical pneumonia. With knowledge of the causal agent, a specific diagnosis can be made. That pulmonary infiltration unassociated with bacterial infection may develop during the course of an upper respiratory viral disease has been amply demonstrated in influenza infections $(15,16)$.

The role of the group of viruses isolated by Rowe, Huebner, and co-workers (5) as causative agents of disease is not yet clear. It is certain, however, that these viruses are different from the RI-67 agent and do not cause the infection, ARD, studied in the present investigation. That upper respiratory infections of similar nature may be caused by one of these agents is possible. Moreover, the data suggest that these viruses are not the etiologic agents of primary atypical pneumonia or common cold infections. Evidence is available, however, that the A.D. agents are to some extent immunologically related to the RII-67 agent: although antigenic resemblances cannot be detected by neutralization techniques, complementfixation titrations reveal that the 3 types of A.D. agents and RI- 67 virus are immunologically related by a common antigen $(6,13$-See Addendum).

The results of the serological studies presented confirm the conclusions of the Commission on Acute Respiratory Diseases that ARD is a distinct clinical upper respiratory disease and that the infection confers an homologous immunity. These data further indicate that although ARD studied in the human transmission experiments was initiated by a single etiologic agent, similar infections which occurred in epidemics were caused not only by this agent, RI-67, but by others still unidentified. It is therefore proposed that agents which are shown to produce the clinical infection recognized as ARD be called ARD viruses; the RI-67 virus, as well as others which may subsequently be isolated, falls into this classification.

\section{SUMMARY}

Sera obtained from donors of infected respiratory secretions and recipients of these secretions during a human transmission experiment carried out by the Commission on Acute Respiratory Diseases, 1945, were employed for neutralization titrations with the RI-67 agent isolated by Hilleman and Werner (6) and the A.D. agents obtained by Rowe and his co-workers (5). These studies indicated that the acute upper respiratory infection, ARD, was caused by an agent, presumably a virus, identical with or closely related to the RI-67 agent; that the A.D. agents did not produce this illness; and that ARD is a clinical entity distinct from the common cold or primary atypical pneumonia. In addition to the RI-67 agent, ARD is probably caused by other agents, immunologically different from the RI-67 virus. It is proposed that the RI- 67 agent be called an ARD virus.

\section{Addendum}

Subsequent to the submission of this paper for publication an article entitled "Adenoidal-Pharyngeal-Conjunctival Agents. A newly Recognized Group of Common Viruses of the Respiratory System," by Huebner, R. J., Rowe, W. P., Ward, T. G., Parrott, R. H., and Bell, J. A. appeared (New England J. Med., 1954, 251, 1077) in which the Adenoid Degeneration Agents and the RI-67 virus isolated by Hilleman and Werner were classified as a single group. This was termed the Adenoidal-Pharyngeal-Conjunctival group of viruses. In this report and the paper which accompanied it (Parrott, R. H., Rowe, W. P., Huebner, R. J., Bernton, H. W., and McCullough, N. M., New England J. Med., 1954, 251, 1087) some of the characteristics of these agents were described, the relationship of the complement-fixing and neutralizing antibodies was indicated, and the isolation of the Type III agent from cases of acute febrile pharyngitis was reported.

\section{ACKNOWLEDGMENT}

The outstanding technical assistance of Miss Mary $\mathrm{K}$. Dixon and Miss Juanita J. McConnell is gratefully acknowledged.

\section{REFERENCES}

1. Commission on Acute Respiratory Diseases, Acute respiratory disease among new recruits. Am. J. Pub. Health, 1946, 36, 439.

2. The Commission on Acute Respiratory Diseases, Clinical patterns of undifferentiated and other acute respiratory diseases in army recruits. Medicine, 1947, 26, 441.

3. The Commission on Acute Respiratory Diseases, Experimental transmission of minor respiratory illness to human volunteers by filter-passing agents. I. Demonstration of two types of illness charac- 
terized by long and short incubation periods and different clinical features. J. Clin. Invest., 1947, 26, 957.

4. The Commission on Acute Respiratory Diseases, Experimental transmission of minor respiratory illness to human volunteers by filter-passing agents. II. Immunity on reinoculation with agents from the two types of minor respiratory illness and from primary atypical pneumonia. J. Clin. Invest, 1947, 26, 974.

5. Rowe, W. P., Huebner, R. J., Gilmore, L. K., Parrott, R. H., and Ward, T. G., Isolation of a cytopathogenic agent from human adenoids undergoing spontaneous degeneration in tissue culture. Proc. Soc. Exper. Biol. \& Med., 1953, 84, 570. Introduced by E. Verder.

6. Hilleman, M. R., and Werner, J. H., Recovery of new agent from patients with acute respiratory illness. Proc. Soc. Exper. Biol. \& Med., 1954, 85, 183.

7. Dingle, J. H., Ginsberg, H. S., Badger, G. F., Jordan, W. S., Jr., and Katz, S., Evidence for the specific etiology of "acute respiratory disease (ARD).” Tr. A. Am. Physicians, 1954, 67, 149.

8. Scherer, W. F., Syverton, J. T., and Gey, G. O., Studies on the propagation in vitro of poliomye- litis viruses. IV. Viral multiplication in a stable strain of human malignant epithelial cells (strain HeLa) derived from an epidermoid carcinoma of the cervix. J. Exper. Med., 1953, 97, 695.

9. Pierce, C. H., Dubos, R. J., and Schaefer, W. B., Multiplication and survival of tubercle bacilli in the organs of mice. J. Exper. Med., 1953, 97, 189.

10. The Commission on Acute Respiratory Diseases, An experimental attempt to transmit primary atypical pneumonia in human volunteers. J. Clin. Invest., 1945, 24, 175.

11. Commission on Acute Respiratory Diseases, The transmission of primary atypical pneumonia to human volunteers. I. Experimental methods. Bull. Johns Hopkins Hosp., 1946, 79, 97.

12. Reed, L. J., and Muench, H.; A simple method of estimating fifty per cent endpoints. Am. J. Hyg., 1938, 27, 493.

13. Ginsberg, H. S., Unpublished data.

14. Horsfall, F. L., Jr., Primary atypical pneumonia. Ann. Int. Med., 1947, 27, 275.

15. Scadding, J. G., Lung changes in influenza. Quart. J. Med., 1937, n.s., 6, 425.

16. Scher, J. M., and Jaruszewski, E., Virus influenza $\mathrm{A}^{\prime}$ infection with pulmonary manifestations. Arch. Int. Med., 1952, 90, 201. 